\title{
Contribution of an educational video to surgical education in laparoscopic appendectomy
}

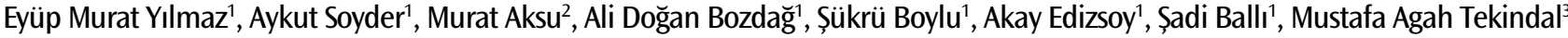

ABSTRACT $\begin{aligned} & \text { Objective: With recent widespread advances in laparoscopy, providing education on this subject has become a } \\ & \text { significant challenge. The aim of this study was to determine the degree of contribution made by surgeons to lapa- } \\ & \text { roscopic education through an educational video. } \\ & \text { Material and Methods: A total of } 40 \text { volunteer general surgery residents and specialists participated in our study. } \\ & \text { Before watching the approximately six-minute educational video prepared for laparoscopic appendectomy, the par- } \\ & \text { ticipants were asked to fill out participant information forms and information measurement questionnaire forms. } \\ & \text { After the video, the participants were asked to fill out the information measurement questionnaire forms a second } \\ & \text { time; additionally, attitude evaluation forms and education evaluation questionnaire forms were presented to the } \\ & \text { participants for completion, and statistical analysis was performed. Furthermore, the total watching duration an- } \\ & \text { dthe number of times the video was paused were recorded. } \\ & \text { Results: A total of } 40 \text { surgeons participated in the study (75\% residents and } 25 \% \text { specialists). When the results of the } \\ & \text { information determination questionnaire forms filled out by the resident and specialist groups before and after the } \\ & \text { video were compared, it was observed that the scores of both groups significantly increased after watching the video } \\ & \text { (p=0.001). A statistical significance was identified between the length of time the video was watched and the educa- } \\ & \text { tion evaluation form scores of the participants (p<0.01). It was observed that the longer the video was watched, the } \\ & \text { greater the increase in the education evaluation scores. The results of the attitude evaluation forms implied that the } \\ & \text { video could be produced more professionally. } \\ & \text { Conclusion: Although education is an inevitable requirement of laparoscopic surgery, many teaching methods are } \\ & \text { available. Awareness-enhancing videos prepared on this topic can be efficient in providing laparoscopic education. } \\ & \text { Keywords: Education, laparoscopic surgery, video }\end{aligned}$

\section{Cite this paper as:} Yılmaz EM, Soyder A, Aksu M, Bozdağ AD, Boylu ş, Edizsoy $\mathrm{E}$, et al. Contribution of an educational video to surgical education in laparoscopic appendectomy. Turk J Surg 2017; 33: 237-242.

'Department of General Surgery, Adnan Menderes University School of Medicine, Aydın, Turkey ${ }^{2}$ Department of Ethics, Izmir University School of Medicine, İzmir, Turkey

${ }^{3}$ Department of Biostatistics, Izmir University School of Medicine, İzmir, Turkey

This study was presented at the $20^{\text {th }}$ National Surgery Congress, 13-17 April 2016, Antalya, Turkey.

Address for Correspondence Eyüp Murat YıImaz e-mail:drmyilmaz80@gmail.com

Received: 11.05.2016 Accepted: 17.06.2016

(c) Copyright 2017 by Turkish Surgical Association

Available online at www.turkjsurg.com

\section{INTRODUCTION}

Laparoscopy is becoming an essential procedure for surgeons. Laparoscopy is frequently being used in very simple to complicated operations and is threatening to replace conventional surgery $(1,2)$. For surgeons to safely apply laparoscopic procedures in daily practice, they should enhance their cognitive and psychomotor skills; surgeons often first perform these procedures on devices such as training boxes or simulators $(3,4)$. In general surgery, advanced laparoscopic surgery procedures are being used daily in many clinics, from basic laparoscopic surgeries such as cholecystectomy and appendectomy to colectomy, bariatric surgery, fundoplication, splenectomy, surrenalectomy, hepatectomy, and the Whipple procedure. These surgical procedures are being taught in two ways. Simulators, such as simple educational boxes, can be used as educational models by increasing skill level and simulating operations without intervention on live patients; they can also be used as video models for measuring surgeons' levels of knowledge of laparoscopic surgery, demonstrating the surgery, and describing technical errors. Furthermore, simulators can be educational tools for determining the contribution of the videos to this subject by re-evaluating the surgeons' knowledge after the education program (5-7). Despite current technological advances, laparoscopic education cannot be sufficiently provided through only a master-apprentice relationship; therefore, it can be useful to provide this education on a periodic basis $(5,8)$.

The aim of this study was to measure the level of knowledge of surgeons on laparoscopic appendectomy, which is one of the most performed operations in surgery clinics; after asking the surgeons to watch an educational video, we evaluated its contribution to their education.

\section{MATERIAL AND METHODS}

This study was performed between October 2015 and November 2015 with approval from the local ethics committee. The study was sponsored by the Scientific Research Project body of Adnan Menderes University. A total of 40 volunteer general surgery residents and specialists participated in the study. 
Participants were informed about the objective of the study, and their written consent was obtained. Surgeons who did not wish to participate were excluded from the study. All the research participants watched the educational video, which was approximately six minutes in lengt hand explained laparoscopic appendectomy surgery, the way it is performed, the trap points and tricks of surgery, and complications; the surgery was demonstrated later. The advantages of the operation and definitions of the instruments and trocar parts were described in the first portion of the video. Brief anatomical information was then provided. Next, the surgical technique was described step by step. Complications were also discussed in the video. Finally, the surgery was shown. However, before the participants watched the video, they were asked to complete two forms: the "participant information form" questionnaire, with the intent of obtaining demographic and occupational information from all participants, consisting of 11 questions; and the "information measurement form" (IMF) questionnaire, with the intent of measuring the participants' level of knowledge, consisting of 20 questions. The questionnaires were administered in person. The IMF questionnaire contained 20 questions, ranging from the number of trochars to insufflation pressure and complications, and was evaluated with 5 points for each correct answer and 0 points for each wrong answer (Table 1). The total scores were found to be between 0 and 100. After completing these questionnaires, the participants watched the video; they paused the video when they wanted to ask a question, then continued watching. At the end of the video, the IMF questionnaire was administered again to evaluate the participants' level of knowledge. Furthermore, to evaluate the contribution of the video to the education of the surgeons, an "attitude evaluation form" questionnaire containing 9 questions and an "education evaluation form" questionnaire containing 23 questions were conducted. The respondents were asked to provide scores between 1 and 5 (1: not good at all, 2: not good, 3: medium, 4: good, 5: very good). Also, the amount of time they watched the video, the number of times they paused the video, and the number of questions asked were recorded. At the end of the study, CDs of the educational video were given to the participants so that they could watch it whenever they wanted.

\section{Statistical Analysis}

The resulting data were analyzed using the Statistical Package for the Social Sciences program (SPSS Inc.; version 17, Chicago, IL, USA). Descriptive statistics (mean, standard deviation, median value, minimum, maximum, number, and percentile) were identified for categorical and continuous variables in the study. The homogeneity of variance, which is a precondition of parametric tests, was also controlled using Levene's test. The assumption of normality was controlled using the Shapiro-Wilk test. To evaluate the differences between the two groups, provided that they satisfied the preconditions of the parametric test, Student's t-test was applied; otherwise, the Mann-Whitney $\mathrm{U}$ test was used. If the differences between two dependent groups satisfied the preconditions of parametric tests, they were evaluated by the matched-pair t-test; otherwise, they were evaluated using the Wilcoxon test. In cases where the relationship between two continuous variables did not satisfy the Pearson correlation coefficient or the preconditions of parametric tests, the data were evaluated using the Spearman correlation coefficient. The test was performed
Table 1. Information measurement form

General surgery laparoscopic appendectomy education information measurement form

Subject: Laparoscopic appendectomy video presentation

Your profile: a. Assistan b. Specialist

Questions

1. What is the number of trocar in laparoscopic appendectomy?

2. Please describe the trocar entry places in laparoscopic appendectomy?

3. What are the trocar diameters in laparoscopic appendectomy?

\section{What is the degree of laparoscope used?}

5. How much $\mathrm{mmHg}$ is the pressure?

6. How is the position of the patient?

7. How is the anesthesia that applied to the patient?

8. Which probes should be attached to patient?

9. How appendix is detected with laparoscopic method?

10. What is the position of surgeon and assistant in laparoscopic appendectomy?

11. What is the critical opinion of laparoscopic appendiceal?

12. Is the group of patient is present that laparoscopic appendectomy is useful for?

13. Provided that your answer is yes in the twelfth question, then please describe these groups.

14. How is appendix's meso separated in laparoscopic appendectomy?

15. How is appendix's root separated in laparoscopic appendectomy?

16. How appendix is taken out of batin after laparoscopic appendectomy?

17. Which organs are under risk at surgery place?

18. Which advantages does laparoscopic appendectomy have as compared to open appendectomy?

19. What are the reasons for short passing?

20. What are the complications?

using retest reliability coefficients and intra-class correlation coefficients. The relationships between categorical variables were analyzed using Fisher's exact test and the chi-square test. In cases where the expected frequency was less than $20 \%$, to include these frequencies in the analysis, the evaluation was conducted by the Monte Carlo simulation method. $\mathrm{P}<0.05$ was considered as statistically significant.

\section{RESULTS}

\section{Participants}

A total of 40 people were included in the study; $80 \%$ of these individuals were male, while $20 \%$ were female. With respect to their educational status, $75 \%$ of the participants were residents, while $25 \%$ were specialists. The average age was 31.08 (min: 27; max: 40) years. Their average period of service was 4.2 (min: 1 ; max: 12) years. 


\section{Laparoscopic Surgery Education}

All the participants stated that they had received training in laparoscopic appendectomy during their residency education. While $17.5 \%$ of the participants stated that they had performed advanced laparoscopic processes as well as appendectomy and cholecystectomy during the period of residency training, $82.5 \%$ stated that they had not attempted any advanced laparoscopic procedures during that time. While the scores of the IMF questionnaire administered before watching the educational video were lower, the scores increased after the video was watched. When the scores of the resident and specialist groups and the genders were compared, it was found that all the scores after watching the video significantly increased $(p=0.001)$. When the scores of all questions included in the attitude evaluation form were compared for the residents and specialists, no statistical difference was determined between the two groups ( $\mathrm{p}: 0.584)$ ). It was found that the education provided after the questionnaires were administered increased the level of awareness $(p=0.306)$; however, participants recommended this training to their colleagues $(p=0.306)$ and felt that this type of education should continue (p:0.584). Also, the answers provided in this form implied that the video could have been produced more professionally.

The average video watching durations of the participants were found to be $7.11 \pm 2.25$ minutes for specialists and $6.10 \pm 1.11$ minutes for residents. A statistical significance was identified between the time that elapsed while the participants watched the video and the scoring of the education evaluation form $(p<0.01)$. It was found that as the elapsed time increased, the education evaluation scores also increased. In addition, regarding the scores of the education evaluation forms, a statistically

Table 2. Respondents demographic data

$\mathrm{N}$ (frequency) Percent (\%)

$\begin{array}{lcc}\text { Sexuality } & 32 & \\ \text { Male } & 8 & 20.0 \\ \text { Female } & & \end{array}$

Educational status

$\begin{array}{lll}\text { Assistant } & 30 & 75.0 \\ \text { Specialist } & 10 & 25.0\end{array}$

\section{Educational institution}

$\begin{array}{lll}\text { University } & 13 & 32.5 \\ \text { Education and research hospital } & 27 & 67.5\end{array}$

Have you applied the method of laparoscopic appendectomy? Yes 40 100.0

Have you received an education with the subject of laparoscopic appendectomy in the education period before graduation?

No

40

100.0

Have you received an education of laparoscopic process under a different title except for laparoscopic appendectomy approach?

\begin{tabular}{lcc} 
Yes & 7 & 17.5 \\
No & 33 & 82.5 \\
\hline Total & 40 & 100.0
\end{tabular}

significant difference was found between the evaluations of the residents and specialists $(p=0.011)$. It was observed that residents gave higher scores when evaluating the video. The frequency values of the education evaluation form are given in Table 2, 3.

\section{DISCUSSION}

Currently, laparoscopy is replacing conventional surgery for many methods, and its widespread importance in daily use is rapidly increasing (9). However, this progress has some disadvantages. If surgery residents are inexperienced, especially in advanced laparoscopy surgeries, they should receive good training in this field (6). Many methods are available to provide this training. Although highly developed and very workable three-dimensional simulation devices are available in this field, their greatest disadvantages are that they are very expensive and are not accessible in every center (10). Additionally, simple and easy-to-operate laparoscopic educational devices are being manufactured. Chen et al. (11) reported that great progress could be achieved in laparoscopic training with simple training boxes that they made themselves. It was revealed in another study by Munz et al. (8) that there was no significant difference between groups operating with laparoscopic simulator devices and simple laparoscopic boxes in practice. It is stated in the literature that similar inexpensive education boxes could contribute to laparoscopic education; however, we considered that a contribution to laparoscopic education could also be provided by conducting questionnaires measuring the laparoscopic education level of surgeons, and after determining this level, identifying the missing aspects of the surgeons' knowledge, asking them to watch educational videos, and then re-measuring their levels of knowledge. We applied this educational method specifically for appendectomy, which is among the most common emergency operations.

While the educational box method is usually highly preferred in laparoscopic education, educational videos have been used in many centers, even in the "problem-based teaching" programs of medical school students $(12,13)$. In this method, participants can note their mistakes and make efforts to correct them; by continuously watching new educational videos, they remember key points and information. We primarily intended to measure the participants level of knowledge with the IMF questionnaire. Before and after watching the video, the participants were asked two questions with very different answers: "How is the appendix detected by laparoscopic methods"? and "What is the laparoscopic appendiceal critical opinion"? These questions, which were generally answered incorrectly by both specialists and resident surgeons before watching the video, were generally answered correctly after watching the video. It was observed that almost all the other questions were answered correctly to a certain extent after the participants watched the video. As a result, we suggest that the educational video had a positive effect on the IMF questionnaire. Although we claim that no statistically significant difference was observed between residents and specialists with respect to the attitude evaluation form, the educational video helped to increase the participants' awareness of laparoscopy, as previously implied by the answers of the participants, and increased their levels of decision-making and skill; in 


\section{Table 3. Education evaluation form}

\begin{tabular}{|c|c|c|c|c|c|c|c|}
\hline & & & Not good at all & Not good & Medium & Good & Very good \\
\hline \multirow[t]{2}{*}{$\begin{array}{l}\text { Was the education arrangement date (timing) } \\
\text { appropriate for you? }\end{array}$} & Assistan & $\begin{array}{l}\mathrm{n} \\
\%\end{array}$ & $\begin{array}{l}1 \\
50.0\end{array}$ & $\begin{array}{l}4 \\
80.0\end{array}$ & $\begin{array}{l}1 \\
20.0\end{array}$ & $\begin{array}{l}19 \\
82.6\end{array}$ & $\begin{array}{l}5 \\
100.0\end{array}$ \\
\hline & Specialist & $\begin{array}{l}n \\
\%\end{array}$ & $\begin{array}{l}1 \\
50.0\end{array}$ & $\begin{array}{l}1 \\
20.0\end{array}$ & $\begin{array}{l}4 \\
80.0\end{array}$ & $\begin{array}{l}4 \\
17.4\end{array}$ & $\begin{array}{l}0 \\
0.0\end{array}$ \\
\hline \multirow[t]{2}{*}{$\begin{array}{l}\text { Was the device required for watching the } \\
\text { education video sufficient? }\end{array}$} & Assistan & $\begin{array}{l}\mathrm{n} \\
\%\end{array}$ & $\begin{array}{l}1 \\
100.0\end{array}$ & $\begin{array}{l}0 \\
0.0\end{array}$ & $\begin{array}{l}4 \\
66.7\end{array}$ & $\begin{array}{l}14 \\
70.0\end{array}$ & $\begin{array}{l}11 \\
91.7\end{array}$ \\
\hline & Specialist & $\begin{array}{l}\mathrm{n} \\
\%\end{array}$ & $\begin{array}{l}0 \\
0.0\end{array}$ & $\begin{array}{l}1 \\
100.0\end{array}$ & $\begin{array}{l}2 \\
33.3\end{array}$ & $\begin{array}{l}6 \\
30.0\end{array}$ & $\begin{array}{l}1 \\
8.3\end{array}$ \\
\hline \multirow[t]{2}{*}{$\begin{array}{l}\text { Was the duration of the education } \\
\text { video enough? }\end{array}$} & Assistan & $\begin{array}{l}\mathrm{n} \\
\%\end{array}$ & $\begin{array}{l}0 \\
0.0\end{array}$ & $\begin{array}{l}0 \\
0.0\end{array}$ & $\begin{array}{l}1 \\
100.0\end{array}$ & $\begin{array}{l}14 \\
77.8\end{array}$ & $\begin{array}{l}15 \\
71.4\end{array}$ \\
\hline & Specialist & $\begin{array}{l}\mathrm{n} \\
\%\end{array}$ & $\begin{array}{l}0 \\
0.0\end{array}$ & $\begin{array}{l}0 \\
0.0\end{array}$ & $\begin{array}{l}0 \\
0.0\end{array}$ & $\begin{array}{l}4 \\
22.2\end{array}$ & $\begin{array}{l}6 \\
28.6\end{array}$ \\
\hline \multirow[t]{2}{*}{$\begin{array}{l}\text { Did the content of education comply with } \\
\text { education's aim and was it sufficient? }\end{array}$} & Assistan & $\begin{array}{l}n \\
\%\end{array}$ & $\begin{array}{l}0 \\
0.0\end{array}$ & $\begin{array}{l}1 \\
100.0\end{array}$ & $\begin{array}{l}4 \\
80.0\end{array}$ & $\begin{array}{l}13 \\
86.7\end{array}$ & $\begin{array}{l}12 \\
63.2\end{array}$ \\
\hline & Specialist & $\begin{array}{l}\mathrm{n} \\
\%\end{array}$ & $\begin{array}{l}0 \\
0.0\end{array}$ & $\begin{array}{l}0 \\
0.0\end{array}$ & $\begin{array}{l}1 \\
20.0\end{array}$ & $\begin{array}{l}2 \\
13.3\end{array}$ & $\begin{array}{l}7 \\
36.8\end{array}$ \\
\hline \multirow[t]{2}{*}{$\begin{array}{l}\text { Was the education place appropriate for } \\
\text { the education? }\end{array}$} & Assistan & $\begin{array}{l}n \\
\%\end{array}$ & $\begin{array}{l}1 \\
100.0\end{array}$ & $\begin{array}{l}0 \\
0.0\end{array}$ & $\begin{array}{l}4 \\
66.7\end{array}$ & $\begin{array}{l}17 \\
77.3\end{array}$ & $\begin{array}{l}8 \\
88.9\end{array}$ \\
\hline & Specialist & $\begin{array}{l}n \\
\%\end{array}$ & $\begin{array}{l}0 \\
0.0\end{array}$ & $\begin{array}{l}2 \\
100.0\end{array}$ & $\begin{array}{l}2 \\
33.3\end{array}$ & $\begin{array}{l}5 \\
22.7\end{array}$ & $\begin{array}{l}1 \\
11.1\end{array}$ \\
\hline $\begin{array}{l}\text { Does the theoretical information displayed } \\
\text { at the educational video comprise } \\
\text { study objectives? }\end{array}$ & $\begin{array}{l}\text { Assistan } \\
\text { Specialist }\end{array}$ & $\begin{array}{l}\mathrm{n} \\
\% \\
\mathrm{n} \\
\%\end{array}$ & $\begin{array}{l}0 \\
0.0 \\
0 \\
0.0\end{array}$ & $\begin{array}{l}0 \\
0.0 \\
0 \\
0.0\end{array}$ & $\begin{array}{l}0 \\
0.0 \\
4 \\
100.0\end{array}$ & $\begin{array}{l}18 \\
90.0 \\
2 \\
10.0\end{array}$ & $\begin{array}{l}12 \\
75.0 \\
4 \\
25.0\end{array}$ \\
\hline \multirow[t]{2}{*}{$\begin{array}{l}\text { Was the surgery images displayed at the } \\
\text { educational video sufficient? }\end{array}$} & Assistan & $\begin{array}{l}n \\
\%\end{array}$ & $\begin{array}{l}0 \\
0.0\end{array}$ & $\begin{array}{l}2 \\
100.0\end{array}$ & $\begin{array}{l}8 \\
72.7\end{array}$ & $\begin{array}{l}7 \\
53.8\end{array}$ & $\begin{array}{l}13 \\
92.9\end{array}$ \\
\hline & Specialist & $\begin{array}{l}\mathrm{n} \\
\%\end{array}$ & $\begin{array}{l}0 \\
0.0\end{array}$ & $\begin{array}{l}0 \\
0.0\end{array}$ & $\begin{array}{l}3 \\
27.3\end{array}$ & $\begin{array}{l}6 \\
46.2\end{array}$ & $\begin{array}{l}1 \\
7.1\end{array}$ \\
\hline \multirow[t]{2}{*}{$\begin{array}{l}\text { Did the points that need to be paid } \\
\text { attention emphasize? }\end{array}$} & Assistan & $\begin{array}{l}n \\
\%\end{array}$ & $\begin{array}{l}0 \\
0.0\end{array}$ & $\begin{array}{l}1 \\
100.0\end{array}$ & $\begin{array}{l}1 \\
50.0\end{array}$ & $\begin{array}{l}14 \\
77.8\end{array}$ & $\begin{array}{l}14 \\
73.7\end{array}$ \\
\hline & Specialist & $\begin{array}{l}n \\
\%\end{array}$ & $\begin{array}{l}0 \\
0.0\end{array}$ & $\begin{array}{l}0 \\
0.0\end{array}$ & $\begin{array}{l}1 \\
50.0\end{array}$ & $\begin{array}{l}4 \\
22.2\end{array}$ & $\begin{array}{l}5 \\
26.3\end{array}$ \\
\hline \multirow[t]{2}{*}{$\begin{array}{l}\text { Did the subject discuss with appropriate } \\
\text { methods and techniques? }\end{array}$} & Assistan & $\begin{array}{l}n \\
\%\end{array}$ & $\begin{array}{l}1 \\
100.0\end{array}$ & $\begin{array}{l}0 \\
0.0\end{array}$ & $\begin{array}{l}0 \\
0.0\end{array}$ & $\begin{array}{l}13 \\
72.2\end{array}$ & $\begin{array}{l}16 \\
80.0\end{array}$ \\
\hline & Specialist & $\begin{array}{l}n \\
\%\end{array}$ & $\begin{array}{l}0 \\
0.0\end{array}$ & $\begin{array}{l}0 \\
0.0\end{array}$ & $\begin{array}{l}1 \\
100.0\end{array}$ & $\begin{array}{l}5 \\
27.8\end{array}$ & $\begin{array}{l}4 \\
20.0\end{array}$ \\
\hline \multirow[t]{2}{*}{$\begin{array}{l}\text { Was time used effectively and efficiently } \\
\text { during education? }\end{array}$} & Assistan & $\begin{array}{l}n \\
\%\end{array}$ & $\begin{array}{l}1 \\
100.0\end{array}$ & $\begin{array}{l}2 \\
100.0\end{array}$ & $\begin{array}{l}3 \\
75.0\end{array}$ & $\begin{array}{l}12 \\
66.7\end{array}$ & $\begin{array}{l}12 \\
80.0\end{array}$ \\
\hline & Specialist & $\begin{array}{l}n \\
\%\end{array}$ & $\begin{array}{l}0 \\
0.0\end{array}$ & $\begin{array}{l}0 \\
0.0\end{array}$ & $\begin{array}{l}1 \\
25.0\end{array}$ & $\begin{array}{l}6 \\
33.3\end{array}$ & $\begin{array}{l}3 \\
20.0\end{array}$ \\
\hline \multirow[t]{2}{*}{$\begin{array}{l}\text { Was the issue clear understandable and } \\
\text { appropriate to your level? }\end{array}$} & Assistan & $\begin{array}{l}\mathrm{n} \\
\%\end{array}$ & $\begin{array}{l}0 \\
0.0\end{array}$ & $\begin{array}{l}1 \\
100.0\end{array}$ & $\begin{array}{l}2 \\
50.0\end{array}$ & $\begin{array}{l}15 \\
71.4\end{array}$ & $\begin{array}{l}12 \\
85.7\end{array}$ \\
\hline & Specialist & $\begin{array}{l}\mathrm{n} \\
\%\end{array}$ & $\begin{array}{l}0 \\
0.0\end{array}$ & $\begin{array}{l}0 \\
0.0\end{array}$ & $\begin{array}{l}2 \\
50.0\end{array}$ & $\begin{array}{l}6 \\
28.6\end{array}$ & $\begin{array}{l}2 \\
14.3\end{array}$ \\
\hline \multirow[t]{2}{*}{$\begin{array}{l}\text { Did you feel need to ask questions to observer } \\
\text { educator while watching the educational film? }\end{array}$} & Assistan & $\begin{array}{l}n \\
\%\end{array}$ & $\begin{array}{l}0 \\
0.0\end{array}$ & $\begin{array}{l}2 \\
66.7\end{array}$ & $\begin{array}{l}6 \\
60.0\end{array}$ & $\begin{array}{l}13 \\
76.5\end{array}$ & $\begin{array}{l}9 \\
90.0\end{array}$ \\
\hline & Specialist & $\begin{array}{l}\mathrm{n} \\
\%\end{array}$ & $\begin{array}{l}0 \\
0.0\end{array}$ & $\begin{array}{l}1 \\
33.3\end{array}$ & $\begin{array}{l}4 \\
40.0\end{array}$ & $\begin{array}{l}4 \\
23.5\end{array}$ & $\begin{array}{l}1 \\
10.0\end{array}$ \\
\hline \multirow[t]{2}{*}{$\begin{array}{l}\text { Did the observer educator answer your } \\
\text { questions? }\end{array}$} & Assistan & $\begin{array}{l}n \\
\%\end{array}$ & $\begin{array}{l}0 \\
0.0\end{array}$ & $\begin{array}{l}0 \\
0.0\end{array}$ & $\begin{array}{l}3 \\
75.0\end{array}$ & $\begin{array}{l}10 \\
62.5\end{array}$ & $\begin{array}{l}17 \\
85.0\end{array}$ \\
\hline & Specialist & $\begin{array}{l}\mathrm{n} \\
\%\end{array}$ & $\begin{array}{l}0 \\
0.0\end{array}$ & $\begin{array}{l}0 \\
0.0\end{array}$ & $\begin{array}{l}1 \\
25.0\end{array}$ & $\begin{array}{l}6 \\
37.5\end{array}$ & $\begin{array}{l}3 \\
15.0\end{array}$ \\
\hline \multirow[t]{2}{*}{$\begin{array}{l}\text { Was any resource recommended to develop } \\
\text { your information? }\end{array}$} & Assistan & $\begin{array}{l}\mathrm{n} \\
\%\end{array}$ & $\begin{array}{l}0 \\
0.0\end{array}$ & $\begin{array}{l}0 \\
0.0\end{array}$ & $\begin{array}{l}1 \\
50.0\end{array}$ & $\begin{array}{l}9 \\
56.3\end{array}$ & $\begin{array}{l}20 \\
95.2\end{array}$ \\
\hline & Specialist & $\begin{array}{l}\mathrm{n} \\
\%\end{array}$ & $\begin{array}{l}1 \\
100.0\end{array}$ & $\begin{array}{l}0 \\
0.0\end{array}$ & $\begin{array}{l}1 \\
50.0\end{array}$ & $\begin{array}{l}7 \\
43.8\end{array}$ & $\begin{array}{l}1 \\
4.8\end{array}$ \\
\hline
\end{tabular}




\begin{tabular}{|c|c|c|c|c|c|c|c|}
\hline \multirow[t]{2}{*}{$\begin{array}{l}\text { Was the presentation sufficient visually } \\
\text { and aurally? }\end{array}$} & Assistan & $\begin{array}{l}\mathrm{n} \\
\%\end{array}$ & $\begin{array}{l}0 \\
0.0\end{array}$ & $\begin{array}{l}0 \\
0.0\end{array}$ & $\begin{array}{l}0 \\
0.0\end{array}$ & $\begin{array}{l}19 \\
86.4\end{array}$ & $\begin{array}{l}11 \\
73.3\end{array}$ \\
\hline & Specialist & $\begin{array}{l}\mathrm{n} \\
\%\end{array}$ & $\begin{array}{l}0 \\
0.0\end{array}$ & $\begin{array}{l}0 \\
0.0\end{array}$ & $\begin{array}{l}3 \\
100.0\end{array}$ & $\begin{array}{l}3 \\
13.6\end{array}$ & $\begin{array}{l}4 \\
26.7\end{array}$ \\
\hline \multirow[t]{2}{*}{$\begin{array}{l}\text { Did education contribute to your } \\
\text { professional development positively? }\end{array}$} & Assistan & $\begin{array}{l}\mathrm{n} \\
\%\end{array}$ & $\begin{array}{l}0 \\
0.0\end{array}$ & $\begin{array}{l}0 \\
0.0\end{array}$ & $\begin{array}{l}1 \\
33.3\end{array}$ & $\begin{array}{l}10 \\
62.5\end{array}$ & $\begin{array}{l}19 \\
95.0\end{array}$ \\
\hline & Specialist & $\begin{array}{l}\mathrm{n} \\
\%\end{array}$ & $\begin{array}{l}1 \\
100.0\end{array}$ & $\begin{array}{l}0 \\
0.0\end{array}$ & $\begin{array}{l}2 \\
66.7\end{array}$ & $\begin{array}{l}6 \\
37.5\end{array}$ & $\begin{array}{l}1 \\
5.0\end{array}$ \\
\hline \multirow[t]{2}{*}{$\begin{array}{l}\text { Did education contribute to your personal } \\
\text { development positively? }\end{array}$} & Assistan & $\begin{array}{l}\mathrm{n} \\
\%\end{array}$ & $\begin{array}{l}1 \\
100.0\end{array}$ & $\begin{array}{l}2 \\
66.7\end{array}$ & $\begin{array}{l}2 \\
66.7\end{array}$ & $\begin{array}{l}15 \\
78.9\end{array}$ & $\begin{array}{l}10 \\
71.4\end{array}$ \\
\hline & Specialist & $\begin{array}{l}\mathrm{n} \\
\%\end{array}$ & $\begin{array}{l}0 \\
0.0\end{array}$ & $\begin{array}{l}1 \\
33.3\end{array}$ & $\begin{array}{l}1 \\
33.3\end{array}$ & $\begin{array}{l}4 \\
21.1\end{array}$ & $\begin{array}{l}4 \\
28.6\end{array}$ \\
\hline \multirow[t]{2}{*}{ Did education bring new knowledge and skills? } & Assistan & $\begin{array}{l}\mathrm{n} \\
\%\end{array}$ & $\begin{array}{c}0 \\
0.0\end{array}$ & $\begin{array}{l}1 \\
100.0\end{array}$ & $\begin{array}{l}0 \\
0.0\end{array}$ & $\begin{array}{l}16 \\
80.0\end{array}$ & $\begin{array}{l}13 \\
76.5\end{array}$ \\
\hline & Specialist & $\begin{array}{l}\mathrm{n} \\
\%\end{array}$ & $\begin{array}{l}0 \\
0.0\end{array}$ & $\begin{array}{l}0 \\
0.0\end{array}$ & $\begin{array}{l}2 \\
100.0\end{array}$ & $\begin{array}{l}4 \\
20.0\end{array}$ & $\begin{array}{l}4 \\
23.5\end{array}$ \\
\hline \multirow[t]{2}{*}{ Did education increase your motivation? } & Assistan & $\begin{array}{l}\mathrm{n} \\
\%\end{array}$ & $\begin{array}{l}0 \\
0.0\end{array}$ & $\begin{array}{l}0 \\
0.0\end{array}$ & $\begin{array}{l}2 \\
66.7\end{array}$ & $\begin{array}{l}14 \\
87.5\end{array}$ & $\begin{array}{l}14 \\
73.7\end{array}$ \\
\hline & Specialist & $\begin{array}{l}\mathrm{n} \\
\%\end{array}$ & $\begin{array}{l}0 \\
0.0\end{array}$ & $\begin{array}{l}2 \\
100.0\end{array}$ & $\begin{array}{l}1 \\
33.3\end{array}$ & $\begin{array}{l}2 \\
12.5\end{array}$ & $\begin{array}{l}5 \\
26.3\end{array}$ \\
\hline \multirow[t]{2}{*}{$\begin{array}{l}\text { Did education bring new knowledge and } \\
\text { skills that you can apply at your institution? }\end{array}$} & Assistan & $\begin{array}{l}\mathrm{n} \\
\%\end{array}$ & $\begin{array}{l}1 \\
100.0\end{array}$ & $\begin{array}{l}0 \\
0.0\end{array}$ & $\begin{array}{l}3 \\
42.9\end{array}$ & $\begin{array}{l}14 \\
77.8\end{array}$ & $\begin{array}{l}12 \\
85.7\end{array}$ \\
\hline & Specialist & $\begin{array}{l}\mathrm{n} \\
\%\end{array}$ & $\begin{array}{l}0 \\
0.0\end{array}$ & $\begin{array}{l}0 \\
0.0\end{array}$ & $\begin{array}{l}4 \\
57.1\end{array}$ & $\begin{array}{l}4 \\
22.2\end{array}$ & $\begin{array}{l}2 \\
14.3\end{array}$ \\
\hline \multirow[t]{2}{*}{$\begin{array}{l}\text { Did education bring new knowledge and } \\
\text { skills that you can share with your collegues? }\end{array}$} & Assistan & $\begin{array}{l}\mathrm{n} \\
\%\end{array}$ & $\begin{array}{l}0 \\
0.0\end{array}$ & $\begin{array}{l}1 \\
100.0\end{array}$ & $\begin{array}{l}4 \\
50.0\end{array}$ & $\begin{array}{l}13 \\
76.5\end{array}$ & $\begin{array}{l}12 \\
85.7\end{array}$ \\
\hline & Specialist & $\begin{array}{l}\mathrm{n} \\
\%\end{array}$ & $\begin{array}{l}0 \\
0.0\end{array}$ & $\begin{array}{l}0 \\
0.0\end{array}$ & $\begin{array}{l}4 \\
50.0\end{array}$ & $\begin{array}{l}4 \\
23.5\end{array}$ & $\begin{array}{l}2 \\
14.3\end{array}$ \\
\hline \multirow[t]{2}{*}{$\begin{array}{l}\text { Did education increase your interest on } \\
\text { the issue? }\end{array}$} & Assistan & $\begin{array}{l}\mathrm{n} \\
\%\end{array}$ & $\begin{array}{l}0 \\
0.0\end{array}$ & $\begin{array}{c}0 \\
0.0\end{array}$ & $\begin{array}{l}4 \\
80.0\end{array}$ & $\begin{array}{l}18 \\
81.8\end{array}$ & $\begin{array}{l}8 \\
61.5\end{array}$ \\
\hline & Specialist & $\begin{array}{l}\mathrm{n} \\
\%\end{array}$ & $\begin{array}{l}0 \\
0.0\end{array}$ & $\begin{array}{l}0 \\
0.0\end{array}$ & $\begin{array}{l}1 \\
20.0\end{array}$ & $\begin{array}{l}4 \\
18.2\end{array}$ & $\begin{array}{l}5 \\
38.5\end{array}$ \\
\hline \multirow[t]{2}{*}{ How would you overview the education? } & Assistan & $\begin{array}{l}\mathrm{n} \\
\%\end{array}$ & $\begin{array}{l}0 \\
0.0\end{array}$ & $\begin{array}{l}1 \\
100.0\end{array}$ & $\begin{array}{l}0 \\
0.0\end{array}$ & $\begin{array}{l}18 \\
75.0\end{array}$ & $\begin{array}{l}11 \\
84.6\end{array}$ \\
\hline & Specialist & $\begin{array}{l}\mathrm{n} \\
\%\end{array}$ & $\begin{array}{l}0 \\
0.0\end{array}$ & $\begin{array}{l}0 \\
0.0\end{array}$ & $\begin{array}{l}2 \\
100.0\end{array}$ & $\begin{array}{l}6 \\
25.0\end{array}$ & $\begin{array}{l}2 \\
15.4\end{array}$ \\
\hline
\end{tabular}

contrast, we were informed that the educational video could be produced more professionally. Although we achieved our goal of increasing the participants' awareness and decisionmaking levels, our video was simple and plain; as we were criticized regarding this issue, we believe that more expensive three-dimensional films should be produced with the intent of increasing surgeons' interest and participation.

Educational videos are currently widely used as a means of communication in conventional surgery. However, few laparoscopic surgery programs have been evaluated by questionnaires to measure surgeons' levels of knowledge and provide corresponding education. Levi et al. (14) stated that in their study performed with two groups, in which an educational box was compared with a video, the two groups gained no advantages over each other with respect to education. In our study, the other parameters we evaluated in the video group were video watching time and the number of repetitions. When we compared resident and specialist surgeons, we found a statistically significant difference between elapsed time while watching the video and educa- tion evaluation form score $(p<0.01)$. It was observed that as the elapsed time increased, the education evaluation score also increased. Residents gave higher education evaluation scores after watching the film $(p=0.011)$. When we reviewed the education evaluation form and questionnaire, we found that the video was useful for laparoscopic education and helped increase the participants' decision-making skills; however, a more professionally produced educational video would provide a greater contribution to surgeons' education.

\section{CONCLUSION}

Good education is currently required for advanced laparoscopy, which is rapidly replacing conventional surgery, and many methods exist to provide this education. Among these, educational videos can both identify levels of knowledge and fill knowledge gaps on this issue, while increasing levels of awareness and decision-making ability. Inexpensive professional educational films produced on this subject are a source of knowledge that all surgeons can draw upon throughout their careers and use when making decisions. 
Video: Laparoscopic appendectomy education video o8.

Ethics Committee Approval: Ethics committee approval was received for this study from the ethics committee of Adnan Menderes University (Number of 2014/477).

Informed Consent: Written informed consent was obtained from patients who participated in this study.

Peer-review: Externally peer-reviewed.

Author Contributions: Concept - E.M.Y., A.D.B.; Design - A.D.B.; Supervision - Ş.B., A.D.B.; Resource E.M.Y., A.D.B., A.S.; Materials - A.E., Ş.B., M.A.T.; Data Collection and/or Processing - E.M.Y., M.A.T.; Analysis and/ or Interpretation - E.M.Y., M.A.T.; Literature Search - E.M.Y.; Writing Manuscript - E.M.Y.; Critical Reviews - Ş.B.

Conflict of Interest: No conflict of interest was declared by the authors.

Financial Disclosure: This study financial support contributed from local scientific research project.

\section{REFERENCES}

1. Rosenthal R, Gantert WA, Scheidegger D, Oertli D. Can skills assessment on a virtual reality trainer predict a surgical trainee's talent in laparoscopic surgery? Surg Endosc 2006; 20: 1286-1290. [CrossRef]

2. Kohls-Gatzoulis JA, Regehr G, Hutchison C. Teaching cognitive skills improves learning in surgical skills courses: a blinded, prospective, randomized study. Can J Surg 2004; 47: 277-283.

3. Fraser $S A$, Feldman LS, Stanbridge D, Fried GM. Characterizing the learning curve for a basic laparoscopic drill. Surg Endosc 2005; 19: 1572-1578. [CrossRef]

4. Dagash $\mathrm{H}$, Chowdhury $\mathrm{M}$, Pierro $\mathrm{A}$. When can I be proficient in laparoscopic surgery? A systematic review of the evidence. J Pediatr Surg 2003; 38: 720-724. [CrossRef]
5. Husslein H, Shirreff L, Shore EM, Lefebvre GG, Grantcharov TP. The Generic Error Rating Tool: A Novel Approach to Assessment of Performance and Surgical Education in Gynecologic Laparoscopy. J Surg Educ 2015; 72: 1259-1265. [CrossRef]

6. Yılmaz EM, Karacan E, Özçiftci VM, Bilgiç E, Özgün H. Contribution of a Simple Training Box in Basic Laparoscopy Training. Medical Journal of Aegean Clinics 2015; 53: 150-152.

7. Bozdağ $A D$, Tansuğ $T$, Derici $H$, Kara C, Sözütek $A$, Karabuğa $T$, et al. Basit ve ekonomik bir laparoskopik eğitim kutusu. Turk J Surg 2009; 25: 82-83.

8. Munz Y, Kumar BD, Moorthy K, Bann S, Darzi A. Laparoscopic virtual reality and box trainers: is one superior to the other? Surg Endosc 2004; 18: 485-494. [CrossRef]

9. Beatty JD.How to build an inexpensive laparoscopic webcambased trainer. BJU Int 2005; 96: 679-682. [CrossRef]

10. Scott Conner C, Hall TJ, Anglin BL, Muakkassa FF, Poole GV, Thompson AR, et al. The integration of laparoscopy into a surgical residency and implication for the training environment. Surgical Endoscopy 1994; 8: 1054-1057. [CrossRef]

11. Chen X, Pan J, Chen J, Huang H, Wang J, Zou L et, al. A Novel Portable Foldable Laparoscopic Trainer for Surgical Education. J Surg Educ; pii: S1931-7204(15)00285-8.

12. Bosse HM, Huwendiek S, Skelin S, Kirschfink M, Nikendei C. Interactive film scenes for tutor training in problem-based learning (PBL): dealing with difficult situations. Interactive film scenes for tutor training in problem-based learning (PBL): dealing with difficult situations. BMC Medical Education 2010; 10: 52. [CrossRef]

13. Schreuder HWR, Van Den Berg CB, Hazebroek EJ, Verheijen RHM, Schijven MP. Laparoscopic skills training using inexpensive box trainers: which exercises to choose when constructing a validated training course Gynaecological surgery. BJOG 2011; 118: 1576-1584. [CrossRef]

14. Levi O, Michelotti K, Schmidt P, Lagman M, Fahie M, Griffon D. Comparison between Training Models to Teach Veterinary Medical Students Basic Laparoscopic Surgery Skills. J Vet Med Educ 2016; 11: 1-8. [CrossRef] 